NBER WORKING PAPER SERIES

HAS THE FINANCIAL CRISIS PERMANENTLY CHANGED THE PRACTICE OF
MONETARY POLICY? HAS IT CHANGED THE THEORY OF MONETARY POLICY?

Benjamin M. Friedman

Working Paper 20128

http://www.nber.org/papers/w20128

NATIONAL BUREAU OF ECONOMIC RESEARCH
1050 Massachusetts Avenue
Cambridge, MA 02138

May 2014

The views expressed herein are those of the author and do not necessarily reflect the views of the National Bureau of Economic Research.

NBER working papers are circulated for discussion and comment purposes. They have not been peerreviewed or been subject to the review by the NBER Board of Directors that accompanies official NBER publications.

(C) 2014 by Benjamin M. Friedman. All rights reserved. Short sections of text, not to exceed two paragraphs, may be quoted without explicit permission provided that full credit, including $(\mathbb{C}$ notice, is given to the source. 
Has the Financial Crisis Permanently Changed the Practice of Monetary Policy? Has It Changed the Theory of Monetary Policy?

Benjamin M. Friedman

NBER Working Paper No. 20128

May 2014

JEL No. E52,E58

\begin{abstract}
I argue in this paper that one of the two forms of hitherto unconventional monetary policy that many central banks have implemented in response to the 2007 financial crisis - large-scale asset purchases, or to put the matter more generically, use of the central bank's balance sheet as a distinct tool of monetary policy - is likely to become part of the standard toolkit of monetary policymaking in normal times as well. As intended, these purchases have lowered long-term interest rates relative to short-term rates, and lowered interest rates on more-risky compared to less-risky obligations. Moreover, their introduction fills a conceptual vacuum that has long stood at the heart of monetary policy analysis and implementation.

By contrast, forward guidance on the future trajectory of monetary policy has been less successful. Public statements by central banks about their actions and intentions will no doubt continue, but transparency for the sake of transparency is not the same as the deliberate attempt to shape market expectations for purposes of achieving specific monetary policy objectives.

Finally, there is a conceptual component to all this as well. In contrast to the last century or more of monetary theory, which has focused on central banks' liabilities, the basis for the effectiveness of central bank asset purchases turns on the role of the asset side of the central bank's balance sheet. The implications for monetary theory are profound.
\end{abstract}

Benjamin M. Friedman

Department of Economics

Littauer Center 127

Harvard University

Cambridge, MA 02138

and NBER

bfriedman@harvard.edu 
Revised

April, 2014

\title{
HAS THE FINANCIAL CRISIS PERMANENTLY CHANGED THE PRACTICE OF MONETARY POLICY? HAS IT CHANGED THE THEORY OF MONETARY POLICY?*
}

\author{
Benjamin M. Friedman \\ William Joseph Maier Professor of Political Economy \\ Harvard University
}

The global financial crisis of 2007-9, together with the economic downturn that it triggered in much of the advanced industrial and post-industrial world, has constituted one of the most significant economic events since World War II. In many countries the decline in production and the associated loss of jobs and incomes and profits have exceeded what occurred in any prior post-war fluctuation. In some countries output and employment have yet to regain their pre-crisis levels. In the financial arena the collapse of major firms, the decline of asset values and consequent destruction of notional wealth, the interruption of credit flows, the loss of confidence both in firms and in credit market instruments, and the fear of default even by well known counterparties likewise represented an experience unseen since the 1930s.

It is no surprise that these events presented particular challenges, and therefore elicited extraordinary responses, from economic policy. Most immediately, governments and central

\footnotetext{
* This lecture was prepared for the conference on Monetary Analysis and Monetary Policy Frameworks organized by Heriot-Watt University, Edinburgh, April 9-10, 2014. In part it draws on some of my recent work, including especially Friedman and Kuttner (2011) and Friedman (2013).
} 
banks undertook rescue operations of hitherto unprecedented scope as well as scale. In many countries the government, or the central bank, or both, extended extraordinary credits to banks and other key firms, created new facilities for directed lending and for purchasing new (for the central bank) classes of assets, recapitalized banks, and even acquired majority ownership of some banks as well as firms in financial lines of business well removed from banking insurance, for example. The U.K. government took an 81 percent share in Royal Bank of Scotland. At the peak, the U.S. government owned more than one-third of the equity in Citigroup, and more than 90 percent of that in AIG. Nor did governments limit these bail-out operations to financial firms. Most prominently, the U.S. Government rescued from failure two of the three large American automobile manufacturers. Which among these diverse actions qualify as classic "lender-of-last-resort" policy will no doubt be the subject of debate for years to come.

The crisis and the ensuing economic downturn placed demands on conventional macroeconomic policies as well. Here, however, significant impediments emerged. In many countries the latitude (or at least the perceived latitude) to use fiscal policy was constrained by what had already been large government borrowing in the years before the downturn. Once incomes and profits began to decline, shrinking tax revenues along the way, concern over rising levels of government debt relative to national income therefore limited the willingness to expand government spending or cut taxes even further.

Moreover, by 2007 the discretionary use of fiscal policy for purposes of damping fluctuations in output and employment had been in more general disrepute for some decades. One practical reason was simply the awareness of lags: lags in recognizing that fiscal stimulus was appropriate in light of current economic conditions, lags in enacting legislation and 
implementing a more expansionary policy stance (especially if it entailed new spending programs), and then lags in the response of private-sector economic behavior. With the typical business downturn lasting only a short time - in the United States, only ten months from peak to trough, on average during the post-war period - a widely accepted view was that by the time discretionary fiscal policy was in place it would most likely be unneeded, and perhaps even destabilizing.

The presumption against discretionary fiscal policy had a theoretical component too. Ever since Milton Friedman's classic work on the permanent income hypothesis and Franco Modigliani's on the life-cycle theory of saving, economists had discounted the effect on spending due to changes in disposable income that are recognizably temporary, and therefore had mostly downplayed the potential usefulness of stimulative tax cuts during a recession. At the same time, the difficulty of modeling involuntary unemployment in a tractable way, together with the economic profession's ever growing fetish for mathematical formalization, progressively led to excluding from the analysis the main reason government spending stimulates economic activity in times of widespread unemployment. (If everyone who wants to work always has a job, then hiring workers to build roads or make products the government buys simply means moving them from one job to another.) Further, both of these specific theoretical biases fit nicely within the profession's more generic presumption that all economic actors are always at interior optima along every relevant dimension of choice, rather than at corner solutions, and the corresponding systematic over-estimation of interest rate and other price effects and under-estimation of income and other quantity effects.

By contrast, what limited the use of conventional monetary policy in responding to the crisis was mostly the force of practical circumstance: the fact that many countries, having 
entered the crisis after a sustained period of low price inflation, soon into it found their shortterm interest rates hitting the zero lower bound. In the United States the Federal Reserve System lowered its target for the federal funds rate from $5 \frac{1 / 4}{4}$ percent in early 2007 to $0-1 / 4$ percent in late 2008. As of the time of writing, more than half a decade later, the target remains $0-1 / 4$ percent. The European Central Bank was raising its main refinancing operations rate as late as mid 2008, but then quickly lowered it from $4 \frac{1}{4}$ percent to 1 percent by mid 2009. One percent is not the same as zero, of course, but the perception that the rate was about as low as the bank could make it clearly limited further cuts. After a confused flurry of actions in 2011, when the bank raised the refinancing rate twice, it then quickly returned it to 1 percent. In a series of steps over the next two years, it then cut the rate to just $1 / 4$ percent.

With conventional monetary policy therefore unable to respond further, many central banks sought out new ways of using the tools at their disposal to stimulate economic activity in the face of the protracted downturn and then sluggish recovery. One way of doing so was, and for many central banks continues to be, further asset purchases on the central bank's account, even with the policy interest rate already at (or near) the zero bound. A second was, and likewise for many central banks continues to be, making public statements intended to influence market participants' expectations of future monetary policy actions. An important question, looking ahead, is whether these innovations in monetary policymaking will prove temporary emergency measures, taken in time of duress, and to be eschewed once the emergency is past or instead will become part of the standard toolkit of monetary policymaking in normal times.

I argue in this paper that one of these two forms of hitherto unconventional monetary policy, large-scale asset purchases - or, to put the matter more generically, use of the central bank's balance sheet as a distinct tool of monetary policy - is likely to persist. The reason for 
thinking so is twofold. First, these actions have been reasonably successful on their own terms. As intended, when used they have lowered long-term interest rates relative to short-term rates, and lowered interest rates on more-risky compared to less-risky obligations. And second, as I explain below, their introduction fills a conceptual vacuum that has stood at the heart of monetary policy analysis for the better part of the last century, ever since the working out of modern central banking.

By contrast, central banks' attempts at guiding market participants' expectations of the future trajectory of monetary policy have been less successful. In part, such statements are merely an aspect of the widely hailed movement to bring central banks more closely within established notions of democratic governance by rendering their operations and decision-making more transparent to the general public. In this respect, public statements by central banks about their actions and intentions will no doubt continue. But transparency for the sake of transparency is not the same as the deliberate attempt to shape market expectations for purposes of achieving specific monetary policy objectives. Whether such attempts have been effective, or can be effective, is a question that requires much research not yet done; and even then, establishing clear evidence is likely to be difficult. Moreover, owing to the nature of speculative securities markets, central banks may never be able to provide "enough" transparency to satisfy market participants. As one astute market observer has put it, full transparency of monetary policy may simply be a will-o'-the-wisp (see Wojnilower 2014).

Finally, there is a conceptual component to all this as well. To the extent that new ways of conducting monetary policy - specifically, asset purchases not associated with changes in the central bank's policy interest rate - remain part of the standard central bank toolkit, in time they will become part of the standard theory of monetary policy as well. (Macroeconomics is a field 
in which theory lags behind experience and practice, not the other way around.) As I argue in concluding, the implications are profound. To put the matter in Tibergen's vocabulary, for decades the relevant theory has conceived of monetary policy as a matter of deploying one policy instrument. Some economists have, on that account, argued for limiting the central bank to pursuing one policy target; others have favored retaining multiple targets and recognizing, as Tinbergen showed, the inevitable incompleteness in attaining them. It is now clear, however, that a central bank operating in an economy with well developed asset markets has at its disposal two policy instruments (and, under some conceptions, perhaps three). Moreover, in contrast to the last century or more of monetary theory, which has focused on central banks' liabilities, the basis for the effectiveness of this new policy instrument turns on the role of the asset side of the central bank's balance sheet. On both counts, to repeat, the implications are profound.

\section{Use of the Central Bank Balance Sheet: Likely to Remain}

Two aspects of central banks' use of their balance sheets as a policy instrument during and following the crisis stand out. One is how quickly, once short-term interest rates approached the zero lower bound, central banks began to purchase large quantities of assets. The second is how much they bought. At the beginning of 2007 the Federal Reserve System's assets totaled $\$ 880$ billion. By yearend 2008 total assets held were $\$ 2.2$ trillion, although most of the increase consisted of advances to banks and other financial firms, and holdings of instruments like commercial paper acquired through directed facilities intended to support specific markets. At yearend 2009 total asset holdings were still $\$ 2.2$ trillion, but in place of these advances and special facilities the Federal Reserve had purchased large quantities of Treasury notes and bonds and, even more so, of mortgage-backed securities. The pattern has continued ever since. By yearend 2013 - five years into the period of zero short-term interest rates - total assets held 
reached $\$ 4$ trillion. The balance sheet had more than quadrupled since the beginning of the crisis.

The Federal Reserve was not alone in pursuing this course, nor was it the most extreme. The Bank of England nearly quintupled its balance sheet, from L85 billion at the beginning of 2007 to L415 billion at yearend 2012. Sweden's Riksbank almost quadrupled its balance sheet, and within a very brief period of time: from $\mathrm{Kr} 199$ billion at the beginning of 2007 to $\mathrm{Kr} 763$ billion at mid 2009. Even the European Central Bank (which, to recall, was still raising its policy interest rate well into the crisis) expanded its balance sheet from just over E1 trillion at the beginning of 2007 to more than E3 trillion in mid 2012.

The point of these asset purchases was sharply different from the usual working of central bank open market operations. There, the object is to move the market equilibrium downward along the interest-elastic demand for reserves on the part of banks and other reserve-holding institutions. Because the central bank must pay for any assets it acquires, open market purchases of assets are simply the way in which the central bank brings about an increase in the quantity of reserves that it supplies to the market. Whether the central bank frames the operation as choosing a larger quantity of reserves, and letting the market determine the corresponding new (presumably lower) equilibrium interest rate, or choosing a lower interest rate and supplying whatever (presumably larger) quantity of reserves the market requires to get there, is irrelevant for this purpose. What matters in practical terms is the impact on the market-clearing short-term interest rate. And the focus is squarely on the liability side of the central bank's balance sheet.

The point of the asset purchases that central banks made in the most recent episode, once short-term interest rates were already at or near zero, was plainly different. Now the object was to lower the interest rates that mattered for the private sector's demand for goods and services, 
taking into account that no private-sector borrower issues default-free obligations or finances its expenditures with overnight borrowing. On grounds of both maturity and default risk, privatesector obligations are not perfect substitutes for default-free overnight instruments in investors' portfolios. When the market is populated primarily by risk-averse investors - as in fact it is - the return on the relevant private-sector obligations therefore depends on more than just the current and expected future level of the overnight rate. In particular, it depends on the quantity of private-sector obligations that investors, collectively, must hold.

Figure 1 illustrates the economics involved. The downward-sloping line labeled AD (for aggregate demand) in the right-hand panel shows the relationship between spending on goods and services and a representative private-sector interest rate - perhaps the long-term corporate bond rate, perhaps the residential mortgage rate - conditional on given expectations of future output and inflation. The downward-sloping line in the left-hand panel, labeled $\mathrm{C}^{\mathrm{S}}$, depicts households' and firms' supply of private securities, as a function of the interest rate on these securities, also for given expectations of future output and inflation. Because market investors can choose between holding long-term securities or rolling over a comparable-duration sequence of short-term instruments, their demand for these private securities depends, among other things, on the interest rate they bear, on the short-term interest rate set by the central bank today, and on investors' expectations of the short-term interest rate in the future. The solid upward-sloping line labeled $\mathrm{C}^{\mathrm{D}}+\mathrm{C}^{\mathrm{CB}}$, depicts private investors' demand for private-sector securities as a function of the interest rate they carry, for given expectations of future incomes, a given value of the policy interest rate set by the central bank today and given expectations of the policy interest rate in the future, plus a given level of holdings of these securities by the central bank. Figure 1 arbitrarily portrays the initial supply-demand equilibrium in the asset market in the left-hand 
panel, labeled point A, at the private-sector interest rate level that, when transposed to the righthand panel, intersects with the aggregate demand curve at the full-employment value, labeled $\mathrm{y}^{*}$.

The story told in Figure1 begins with some adverse shock of the kind that figured prominently in triggering the recent financial crisis: a decline in house prices, or realized loan losses that deplete lenders' capital, or even simply investors' concern that the economy may be heading into a period of slow growth of incomes and profits in which private-sector borrowers' creditworthiness will be under stress. Any or all of these events reduces private investors' demand for private-sector securities and therefore, all else equal, shifts the demand curve $\mathrm{C}^{\mathrm{D}}+$ $\mathrm{C}^{\mathrm{CB}}$ in the left-hand panel backward to the respective broken line. The result is a higher marketclearing private-sector interest rate, and therefore (in the right-hand panel) a reduced value of output, at the respective points labeled B.

When short-term interest rates are not limited by the zero lower bound, the central bank would traditionally choose to reduce its policy interest rate. Because the overnight instrument being priced in the reserves market is substitutable (though, importantly, not a perfect substitute) for longer-term private-sector securities in investors' portfolios, doing so would then shift the demand for private-sector securities so as to reduce the private interest rate as well (though not one-for-one). If the central bank lowers its policy interest rate by enough, it can thereby restore output to its original level, after sufficient time for the relevant behavioral lags to work themselves out.

Ever since the 2007-9 crisis, however, the policy interest rate has been at or near zero and so further cuts were not an available option. The asset purchases that central banks made therefore had a different purpose. In Figure 1 these purchases are a straightforward addition to the total market demand for private-sector securities, and so they shift the demand curve $\mathrm{C}^{\mathrm{D}}+$ 
$\mathrm{C}^{\mathrm{CB}}$ in the left-hand panel outward to the dotted line, thereby lowering the market-clearing private interest rate for given expectations and a given (presumably zero) policy interest rate. The corresponding result in the right-hand panel is an increase in output. In each panel the intersection that results from this central bank asset purchase is labeled as point $\mathrm{C}$. The figure illustrates the presumably realistic case in which the central bank's purchases are not sufficient to restore output to the initial full-employment level.

The analytics behind central bank asset purchases are clear enough. But is there evidence that they actually worked in this way? As of yearend 2013 there were more than a dozen empirical studies of the experience of this kind of policy action in the United States during and in the wake of the financial crisis (see Williams 2013, Table 1). (There was also some empirical work on this subject, including some of mine, from long before the crisis.) The point estimates of the policy's effectiveness in lowering long-term interest rates, scaled to a $\$ 600$ billion asset purchase (the size of the Federal Reserve's "QE2" round of bond buying), ranged from a low of 10 basis points to a high of 100 basis points. Excluding the high and low, the mean point estimate across the others was 24 basis points - not enormous, especially in light of conventional estimates of the interest elasticity of aggregate demand, but a worthwhile contribution to the economic recovery process nonetheless, and one that Federal Reserve policymakers were clearly glad to embrace.

Given the reliance of households and firms on borrowing that is both long-term and potentially subject to default, the attractions to monetary policymakers of this kind of direct influence on private-sector interest rates are readily apparent. Moreover, as numerous Federal Reserve statements argued, the interest rate effect illustrated in Figure 1 was probably reinforced by corresponding movements in equity prices and in the foreign exchange value of the dollar 
(although in the case of exchange rates any conclusion is of course conditional on the assumption made about the policy stance underlying the other currency).

Further, the composition of the assets that the central bank buys matters too. In the U.S. experience, the Federal Reserve has not merely bought long-term assets but mortgage-backed securities in particular; as of yearend 2013 the Federal Reserve held nearly $\$ 1.5$ trillion of such securities, out of a total balance sheet of just under $\$ 4$ trillion. The intended effect has been to narrow the spread between the interest rates on mortgage borrowing versus comparable-maturity Treasury obligations, and thereby to arrest the downward trend in house prices as well as to stimulate new residential construction. In light of the role of the mortgage market as the epicenter of the financial crisis, with consequent effects on residential construction - U.S. homebuilding declined from 2.1 million new houses started in 2005 to just 554,000 in 2009 - the central bank's interest in stimulating demand in this one sector of the economy in particular is easily understandable. Although clear evidence on the effectiveness of these mortgage purchases on new construction remains to be gleaned from careful research yet to be done, on the surface it appears that at least the attempt to narrow mortgage-versus-Treasury interest rate spreads was indeed effective.

The value to monetary policy of this kind of influence - on long-term interest rates in general and specific interest rates like the mortgage rate in particular, on equity prices, on exchange rates - does not vanish just because the short-term interest rate that the central bank normally uses as its policy interest rate is above zero and potentially subject to being lowered. As a result, in all likelihood central banks will continue to use some form of asset purchases and, conversely, asset sales - at least from time to time, once the zero lower bound is no longer binding. Nor does the story hold merely for the Federal Reserve. There is little reason to think 
policymakers at other central banks that operate in economies with well developed asset markets are not subject to the same economic logic.

The potential usefulness of such portfolio actions is not limited to attempts to stimulate or restrain aggregate economic activity. During the years before the crisis, for example, when U.S. house prices were rising at very rapid rates and homebuilding had likewise reached extremely high levels, many observers of monetary policy urged Federal Reserve policymakers to tighten monetary policy to arrest the developing "bubble" in the mortgage and housing markets. The frequently expressed concern, however, was that raising short-term interest rates was a "blunt" instrument with which to attack a "bubble" in one specific sector of the economy. By contrast, if the central bank can deploy its balance sheet separately from its setting of its policy interest rate - and, if a part of its balance sheet is its holdings of mortgage-backed securities, which it can either enlarge or reduce in order to lower or raise mortgage rates relative to other interest rates it can take more directed action in the event of a situation like the one that preceded (and, in the eyes of many economists, precipitated) the crisis.

What are the potential drawbacks associated with using asset purchases or sales, especially on a large scale, as an instrument of monetary policy? The public discussion to date has brought out two. One is the risk that the central bank may suffer portfolio losses, either from fluctuation in the market value of longer-maturity obligations or from default by private-sector issuers. To date neither has eventuated. Conversely, holding the securities that central banks purchased during and in the aftermath of the crisis has delivered record portfolio profits to those that pursued this course. Moreover, while central bank portfolio losses would represent a form of negative seigniorage, and therefore ultimately impose a burden on taxpayers should they 
occur, there is no real risk to the central bank itself; unlike private banks, central banks do not need positive capital.

The other risk that some economists have alleged follows from the fact that, because asset purchases require payment, when a central bank enlarges its asset holdings it simultaneously increases its outstanding liabilities - and, according to traditional monetary theory, a larger quantity of central bank liabilities means a higher general price level for goods and services in the economy. I return to this matter before concluding.

\section{Forward Guidance: A Matter More Theological than Practical}

A second policy tool to which some central banks turned in the crisis and its aftermath, in the absence of the ability to cut the policy interest rate any further, was forward guidance with respect to their own future actions. When the Federal Reserve reduced its target for the federal funds rate to $0-1 / 4$ percent, in December 2008, the Open Market Committee publicly stated that "the Committee anticipates that weak economic conditions are likely to warrant exceptionally

low levels of the federal funds rate for some time." Apart from a change in wording from "some time" to "an extended period," the Committee repeated the same public statement following each meeting that it held through June 2011. In August 2011, it then switched to a more explicit, calendar-based statement that "the Committee currently anticipates that economic conditions ... are likely to warrant exceptionally low levels for the federal funds rate at least through mid2013." Thereafter, the Committee extended the specific horizon for this forward guidance several times, by late 2012 indicating the anticipation of low short-term interest rates "at least through mid-2015." In December 2012 the Committee shifted to yet a new form of statement explicitly conditioned on observed and forecast economic outcomes rather than a specific calendar date: "the Committee ... currently anticipates that this exceptionally low level for the 
federal funds rate will be appropriate at least as long as the unemployment rate remains above 6 $1 / 2$ percent, inflation between one and two years ahead is projected to be no more than a half percentage point above the Committee's 2-percent longer-run goal, and longer-term inflation expectations continue to be well anchored."

In January 2014 the Open Market Committee changed the language of its regular statement once again, to emphasize that if the U.S. unemployment rate (then measured as 6.7 percent for the month before) were to fall below $6 \frac{1 / 2}{2}$ percent, this event alone would not necessarily trigger an increase in the target federal funds rate: "In determining how long to maintain a highly accommodative stance of monetary policy, the Committee will also consider other information, including additional measures of labor market conditions, indicators of inflation pressures and inflation expectations, and readings on financial developments. The Committee continues to anticipate, based on its assessment of these factors, that it likely will be appropriate to maintain the current target range for the federal funds rate well past the time that the unemployment rate declines below 6-1/2 percent, especially if projected inflation continues to run below the Committee's 2 percent longer-run goal."

Figure 2, analogous to Figure 1, illustrates the working of forward guidance of the kind that the Federal Reserve has been employing ever since its target for the federal funds rate reached zero. The initial movement from the respective points labeled A in each panel to those labeled B again follows from a decline in the value of borrowers' collateral, or realized loan losses that deplete lenders' capital. Longer-term securities are imperfect substitutes for a comparable-duration sequence of short-term instruments in private investors' portfolios, but they are substitutes nonetheless. Lowering the policy rate that investors expect to prevail in the future therefore shifts the demand curve for longer-term securities downward, once again also lowering 
the market-clearing private interest rate, as indicated by the dotted line in the left-hand panel of the figure, and correspondingly raising output in the right-hand panel, in each case to the point labeled C. (With the linear demand for securities curve drawn here, the downward movement due to a lower expected future policy rate in Figure 2 is visually indistinguishable from the outward movement due to greater central bank purchases in Figure 1; but the movement in the demand curve due to forward guidance is vertical, not horizontal.) Here again, the figure illustrates the case in which the effect of the central bank's forward guidance is not sufficient to restore income to the initial level - presumably because of the zero lower bound on the policy interest rate.

As in the case of asset purchases, therefore, the economic logic is clear enough. But is there evidence of market effects along these lines? And are there other potential problems associated with forward guidance regarding future monetary policy actions?

There is some evidence, from experience before the crisis as well as after, of limited effects on market interest rates associated with this kind of announcement by the Federal Reserve (see, for example, Gurkaynak et al. 2007 and Williams 2013, Table 2). As other central banks have taken up the practice as well, albeit more recently and mostly in more limited ways, no doubt further evidence will accumulate. But there are familiar episodes as well in which the effect of such statements of intentions regarding future central bank actions has been counterproductive, at least from the perspective of the objective apparently motivating the statements in the first place.

Most prominently, when Federal Reserve officials first referred publicly, in the spring of 2013 , to the likely cut-back and eventual termination of its ongoing program of continual purchases of Treasury and mortgage-backed securities, the immediate reaction in the U.S. bond 
market raised interest rates on these obligations by well more than almost all available estimates of the bond purchase program's total effect to that time. Attempts by the Open Market Committee to blunt the impact of having begun to discuss the end of the bond purchase program were of little success. (In January 2014, for example, the Committee stated that it "will continue its purchases of Treasury and agency mortgage-backed securities ... until the outlook for the labor market has improved substantially in the context of price stability.") When, and at what pace, the Federal Reserve will diminish the volume of these purchases has continued to be a subject of intense market speculation. Whether, and if so at what pace, the Federal Reserve will then reduce the size of its asset portfolio by outright sales is even more so.

Part of the problem here lies in the nature of speculative asset markets. Theorists of monetary policy often work with models in which the structure of the relevant expectations on the part of financial market participants, and of private economic agents more generally, is extremely simple. In some familiar models, the only aspect of monetary policy that influences economic agents' behavior is the central bank's long-term inflation target. The world in which actual central banks operate is different. Even if the central bank steers its monetary policy according to a fixed inflation target, as in the case of the Bank of England, participants in the securities markets still want to know just how much departure from the inflation target policymakers will tolerate, and under what circumstances, before they decide to raise or lower the bank's policy interest rate, or buy or sell assets, or engage in any of a variety of other policy actions. If the central bank follows a more loosely defined inflation targeting regimen, as in the case of the European Central Bank, or has explicit multiple policy objectives, as the Federal Reserve does, the opportunities for such speculation are all the richer. 
The crucial point is that market participants are in the business of speculating, for profit, on the actions that the central bank takes and the timing with which it takes them. No matter what level of transparency and disclosure the central bank provides, therefore, unless it locks its policy trajectory into determination under a rigid formula, which it publicly discloses and pledges to follow without departures, the market will inevitably want to know more than policymakers can possibly disclose. And even then, the central bank's no-departures pledge may well not be fully credible, so that market participants will continue to speculate about policymakers' actions - although in this case the speculation is framed in terms of whether, and if so under what circumstances, they will violate their pledge to adhere to the formula.

As a result, the likely future of forward guidance as an explicit tool of monetary policy implementation - rather than an adjunct to ongoing policy, simply seeking, for reasons of good governance, to deliver as much transparency as is practically achievable - is dubious. In the absence of new research showing an effect of the forward guidance undertaken since the crisis that is not yet evident, this addition to post-crisis monetary policymaking is not likely to feature prominently in future practice.

Implications for the Theory of Monetary Policy

The experience of the $2007-9$ crisis and its aftermath is also likely to change how macroeconomic theorists view monetary policy. The most straightforward change affects the traditional "quantity theory" - more fully, the quantity-of-money theory of the price of money. The huge increase in asset holdings with which many central banks responded to the crisis meant an equally huge increase in their outstanding liabilities. Theorists who view the macroeconomy through the lens of central bank (or "high powered") money supply therefore expected not just some increase in these economies' rates of inflation but a hyperinflation, perhaps even 
reminiscent of what occurred in Germany and Russia after World War I or in Hungary after World War II. Some well known economists predicted just such a consequence of these extraordinary central bank actions.

But no such increase in inflation - not even a few percentage points - has yet appeared, in any of these economies. To be sure, no one can preclude with certainty even that a hyperinflation, or something like it, may ensue some time somewhere. But even if inflation in these countries does pick up pace at some point, a response of some percentage points to this magnitude of increase in central bank liabilities, and only after a delay of more than half a decade, is sharply at variance with the core implications of standard quantity-theory models relating prices to central bank money. The familiar idea, from generations of textbooks, is that doubling the quantity of central bank liabilities (or "monetary base") would lead to a doubling of the price level - not just a few percentage points' increase in the temporary rate of inflation. In some of the major economies, the quantity of central bank liabilities has not just doubled but quadrupled.

There is an empirical side to this theoretical challenge as well. Corresponding to the generations of textbooks based on the quantity theory, several generations of empirical research in monetary economics - article after article, in one scholarly journal after another - documented empirically the relationship between one or another economy's price level and the quantity of liabilities issued by its central bank. Now, however, given the huge magnitude of the expansion in central bank balance sheets during and following the 2007-9 financial crisis, and especially in light of the weight that least-squares statistical methods attach to outlier observations, for at least the next generation no one will again be able to find economically sensible estimates, for any of 
the large high-income economies, from what were once standard regressions relating the price level (or its rate of change) to the quantity (or change) of central bank liabilities.

But there is a more fundamental theoretical implication of what has happened as well. For decades, the common understanding has been that monetary policy has only one independent instrument at its disposal: it can set the quantity of its outstanding liabilities, or it can set their market price - that is, the interest rate at which they are exchanged - but it cannot independently set both. In modern times, with some exceptions like the period of monetary targeting in many countries in the 1970s and 1980s, most central banks have chosen to carry out monetary policy by setting the interest rate corresponding to banks' holdings of reserves at the central bank. In their response to the $2007-9$ crisis, most of the major central banks initially used the interest-rate instrument and then, once the policy interest rate had reached the lower bound, turned to the quantity instrument. Viewed from this perspective, in each phase of the response to the crisis the central bank was, as in the traditional understanding, still using only one monetary policy instrument at a time.

But the ongoing discussion of monetary policy in the post-crisis recovery has made clear that, under arrangements now in place in most of the high-income economies - specifically, with the central bank able to pay interest on banks' reserve balances - monetary policymakers need not deploy only one of these instruments at a time. The central bank's ability to choose what quantity of assets to purchase (with consequent increase in its liabilities) is not merely an artifact of the policy interest rate's being at the lower bound. Paying interest on reserves establishes a floor to short-term market interest rates, and importantly, it does so without the central bank's needing to carry out conventional open market operations. Lending reserves to the market at a given interest rate, as central banks have traditionally done, likewise establishes a ceiling to 
short-term market interest rates, and again does so without the requiring open market operations.

Not only does the central bank therefore not need to use changes in its asset holdings and liabilities outstanding to move the policy interest rate, but under these institutional arrangements it can even change the quantity of its assets and liabilities in the opposite direction to what would correspond, under the traditional theory of open market operations, to whatever change in the policy interest rate it is implementing at the same time. Given today's institutions, therefore, the central bank can choose, independently, both the quantity of its outstanding assets and liabilities and the market price at which its liabilities trade - in other words, the policy interest rate. In short, monetary policy has not one independent instrument but two.

Further - although here the evidence is not fully in - the composition of the central bank's asset holdings plausibly matters as well. It certainly did during the crisis, when central banks stepped in (or in some cases merely announced that they were prepared to step in) to restore functionality to broken markets by buying assets from which private investors had turned away: in the United States, first commercial paper and then mortgages, and in Europe the sovereign debt of specific countries facing extraordinary fiscal burdens. Fixing broken markets is not the same as conducting monetary policy in ordinary times, and so it remains to be seen whether the composition of the central bank's asset portfolio represents yet a third instrument of monetary policy, in addition to the size of the asset portfolio and, of course, the short-term interest rate. But at a minimum, the theory of monetary policy now needs to recognize the existence of two independent policy instruments - a short-term interest rate and the size of the central bank's asset portfolio - rather than just one as in traditional theory.

And implicit within this recognition is a further, equally fundamental, change in the theory of monetary policy. Since its inception as a recognizable line of economic thinking, the 
focus of monetary theory has been on the liability side of the central bank's balance sheet. By its very name, "monetary" theory concentrates on the "money" that central banks issue, sometimes distinguishing currency versus reserves but sometimes simply aggregating the two forms of liabilities into "high-powered money" or the "monetary base." This is what the quantity theory, for example, was about. The fact that central banks also hold assets has largely been ignored. To be sure, the open market operations conventionally used to move the central bank's policy interest rate involve asset purchases or sales, but these transactions are, according to the usual theory, merely the way in which the central bank creates or withdraws reserves.

By contrast, the new tool that central banks have deployed during and in the wake of the crisis is the size of their asset portfolios. Because the balance sheet must balance, for a central bank no less than any other entity, this increase in assets held has meant a corresponding increase in liabilities outstanding. But instead of the change in assets being a sideshow in the creation or withdrawal of reserves, as in traditional open market operations, during this period the change in the asset portfolio has been essential, while the corresponding increase in central banks' liabilities has been merely the passive - and, for macroeconomic purposes, mostly irrelevant counterpart of the increase in assets that stands at center stage. Policymakers' decisions, and whatever economic effects have ensued, have been a matter of the asset side of central banks' balance sheets, not their liabilities.

Further, between these two now-independent instruments of monetary policy - the size of the central bank's asset holdings and the policy interest rate, to be set by other means - it is presumably the short-term interest rate to which policymakers will look, under most circumstances, to steer aggregate demand, and thereby to influence the economy's price level. The size of the central bank's balance sheet, whether measured by assets or liabilities, may move 
in accordance, but may not. There is no reason to expect the quantity of central bank assets held or liabilities outstanding to bear any particular relationship to the short-term interest rate, or to aggregate demand, or to the price level. The quantity theory has become meaningless, regardless of which quantity the theorist chooses to look at.

As always in macroeconomics, the theory will recognize the new reality only reluctantly. But the reality is now different in the wake of the 2007-9 crisis, and in time the theory must recognize this aspect of it too or become even more irrelevant.

\section{References}

Friedman, Benjamin M., and Kenneth N. Kuttner (2011). "Implementation of Monetary Policy: How Do Central banks Set Interest Rates?" Friedman and Woodford (eds.), Handbook of Monetary Economics, vol. 3B. Amsterdam: Elsevier.

Friedman, Benjamin M. (2013). "The Simple Analytics of Monetary Policy: A Post-Crisis Approach." Journal of Economic Education, 44 (October-December), 311-328.

Gurkaynak, Refet S., Brian Sack, and Jonathan H. Wright (2007). "The U.S. Treasury Yield Curve: 1961 to the Present.” Journal of Monetary Economics, 54 (November), 2291-2304.

Williams, John C. (2013). "Lessons from the Financial Crisis for Unconventional Monetary Policy.” NBER Conference, Boston (October 18).

Wojnilower, Albert M. (2014). “Calm on the Surface.” New York (March 14). 

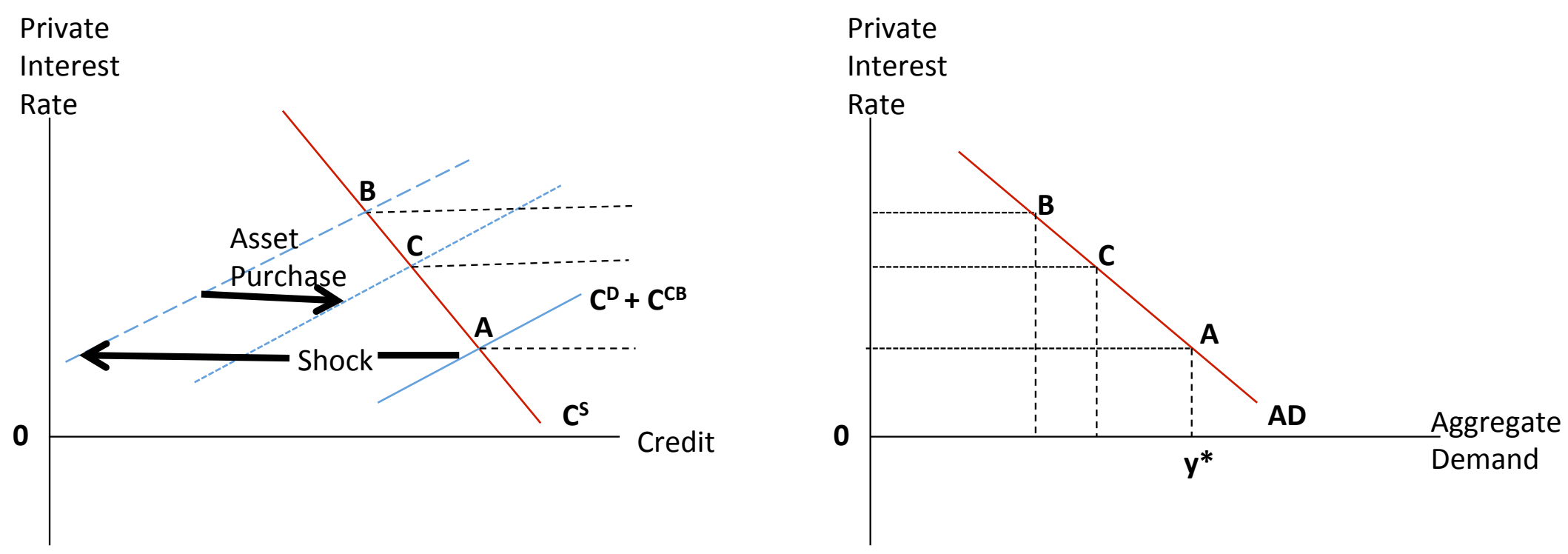

\section{FIGURE 1}

EFFECT OF AN ASSET PURCHASE 

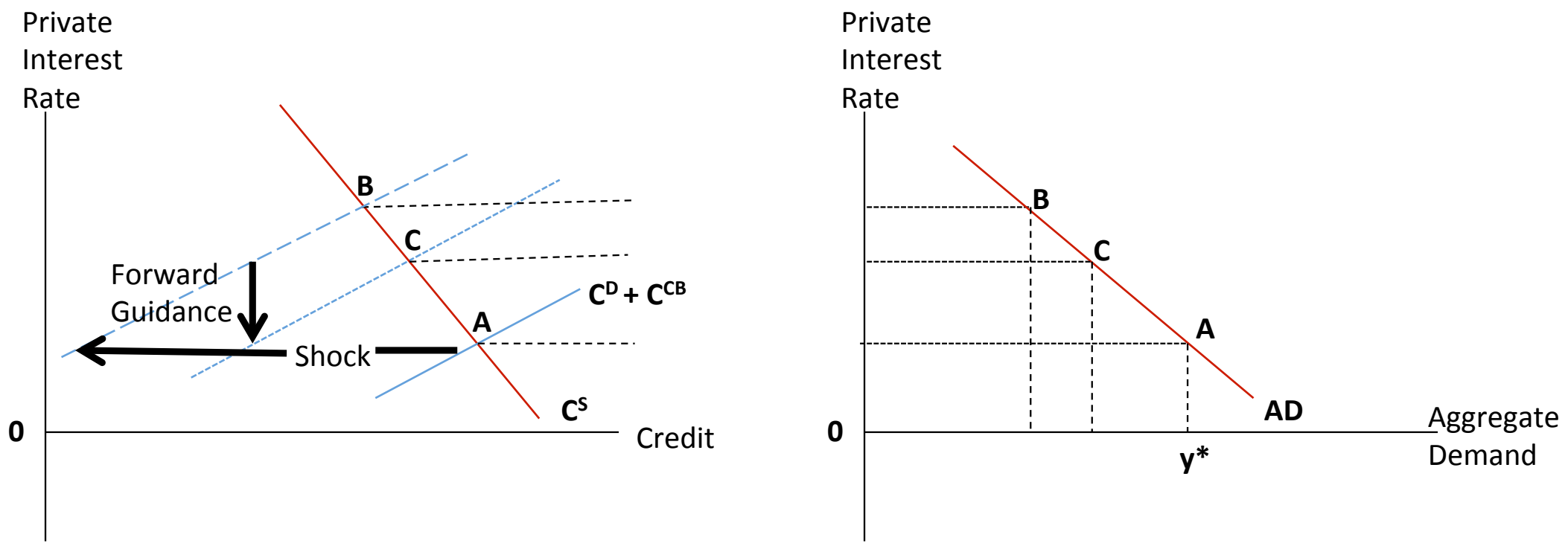

\section{FIGURE 2}

EFFECT OF FORWARD GUIDANCE 